\title{
ANTIENTROPIC TOOLS FOR PROVIDING SUSTAINABLE BALANCED REGIONAL DEVELOPMENT
}

\author{
Volodymyr Vakulenko', Viktoriia Koltun²
}

\begin{abstract}
The purpose of the paper is to substantiate antientropic tools for managing processes of balanced sustainable development of regions. It is shown that one of the most complicated and important contradictions in the system of territorial administration is the contradiction between the development and sustainability of such a complex multidimensional system as a region. And, obviously, relevant scientific task arises as regards to the development of modern approaches to the justification of instruments of dialectical "removal" of the specified contradiction. It is revealed that an optimal methodological step will be the introduction of antientropic approach in the processes of realization of balanced sustainable regional development. Methodology. The survey is based on the actual methodological complex that is characterised by integrity and, including classical postulates which provide its verification, it has innovative aspects. The mentioned approach is based on systems theory that is characterised today by worldwide-recognized universal cognitive tools and antientropic approach, which is in focus of contemporary interdisciplinary studies. Results. Modern approaches to phenomena of entropy are generalized; antientropic paradigm of management of processes of introducing modern model of balanced development at the regional level are substantiated; on the basis of antientropic paradigm, there is proposed a set of approaches to managing organizational processes in the system of local self-government, which provides for permanent dynamic multi-vector interaction of systems (organizations) of different levels and different environments, also it is used for ensuring coherent dissipative activity. Based on the concept of adaptive management, a complex of tools for managing organizational processes in the system of subjects of providing sustainable balanced regional development is elaborated. Practical implications. Proposals on the application of antientropic tools for providing sustainable balanced development of regions can be used by executive authorities and local self-government bodies in the process of formation and implementation of state regional policy, first of all, the Ministry of Regional Development, Construction, Housing and Communal Services of Ukraine during the formation of the State Sustainable Development Strategy and action plan for its implementation, as well as regional administration bodies when designing regional development strategies and implementing appropriate measures, selecting programs (projects) of regional development. Key scientific achievements of this paper also can be used in the process of drafting legal acts, elaborating the Administrative Reform Concept, and implementing other state program documents. Value/originality. Tools that are proposed in this research for introducing the model of balanced sustainable regional development on the basis of antientropic paradigm include the following: maintenance of an open state of the system; use of the principle of feed-forward control; realization of the principle of diversity. The presented complex of approaches ensures continuous dynamic multi-vector interaction of systems (organizations) of different levels and different environments.
\end{abstract}

Key words: investments, financing, public administration.

JEL Classification: D78, H70, R58

\section{Introduction}

As it is noted in a number of documents determining vectors of state regional policy, the current state of regional development is characterised, in particular, by the following: "long-lasting formation of inefficient system of public administration of regional development and non- transparent financing mechanism of regional development, lack of clearly defined state policy in the sphere of regional development..." (Postanova KMU, 2014).

Reflected in modern publications imperatives of research on the management of sustainable development of regions allow arguing that one of the most complicated

Corresponding author:

${ }^{1}$ National Academy of Public Administration under the President of Ukraine, Ukraine.

E-mail: vmvakulenko@gmail.com

${ }^{2}$ National Academy of Public Administration under the President of Ukraine, Ukraine.

E-mail:v_koltun@yahoo.com 
and important contradictions in the administrative system is the contradiction between development and sustainability of such a complex multidimensional system as a region. And, obviously, relevant scientific task arises as regards to the development of modern approaches to the justification of instruments of dialectical "removal" of the specified contradiction.

Therefore, it seems relevant to develop a methodological complex that would be characterised by integrity and, including classical postulates which provide its verification, would have innovative aspects. In our deep conviction, the mentioned approach should be based on systems theory, which is characterised today by worldwide-recognized universal cognitive tools, and antientropic approach, which is in focus of contemporary interdisciplinary studies.

The purpose of the article is to substantiate antientropic tools for managing processes of balanced sustainable development of regions. It is shown that one of the most complicated and important contradictions in the system of territorial administration is the contradiction between the development and sustainability of such a complex multidimensional system as a region. And, obviously, relevant scientific task arises as regards to the development of modern approaches to the justification of instruments of dialectical "removal" of the specified contradiction. It is revealed that an optimal methodological step will be the introduction of antientropic approach in the processes of realization of balanced sustainable regional development.

\section{Balancing dynamic and static characteristics of the development of a multidimensional system - region}

The issue of trends and prospective directions of regional development has recently shown increased interest but this problem is not deeply studied in the scientific literature. A. Kilienene, I. Macherinskene, V. Navitskas and Zh. Simanavichene define tactical actions to strengthen the region through sustainability, namely: "reliance on local resources, increased internal regional turnover, confidence-building among key social groups in the region" (Kilienene, Macherinskene, Navitskas, Simanavichene, 2006). All that they mentioned is reflected today in trends of regional development and Ukraine: the preconditions are formed for the reliance on local resources and increase in the domestic regional turnover, which is manifested in import substitution, strengthening of trust among the key social groups in the region, which involves coordination of actions of the authorities and society. At the same time, given the ambiguity of interpretations of "sustainability" and "stability" as properties of development, the need arises to solve the problem of balancing dynamic and static characteristics of the development of a multidimensional system - region.
Therefore, it is extremely relevant to develop new and improve existing methodological approaches aimed at bringing the system of management of regional development to the required optimal state, that is, to substantiate antientropic paradigm of management of processes of introducing a model of balanced sustainable development.

The problems of entropy and anti-entropy of social systems, in particular, management organizations, were addressed by domestic and foreign specialists. Among the most famous works that determined the vector of this study, it is worthwhile to indicate the works (Mylner, 2000; Luniachek, 2011). They give a thorough vision of phenomena of entropy and anti-entropy using a powerful physical and mathematical apparatus. However, the issues of management of antientropic tools for balanced sustainable development of regions were not studied. Therefore, the modern state of theory and practice of public administration predetermined the choice of the direction of this study.

The search for a given methodological approach in related sciences seems obvious. Ya. Vykliuk writes: "Today, more and more scientific papers are devoted to the application of physical laws for the modelling of economic and social systems... The application of laws of thermodynamics for studying ecosystems and socioeconomic systems allowed showing that these systems should be understood as thermodynamically open. The use of methods of physico-mathematical modelling allowed defining entropy and assessing risks of the functioning of the socio-economic system. Note that the application of thermodynamic laws also indicated a high level of their adequacy in models of urban management" (Vykliuk, 2010).

L. M. Gumilev writes about the dynamic system: "...the system should permanently remove the accumulated entropy by interchanging energy and entropy with the environment. Such an exchange is regulated by management systems..." (Gumilev, 2008). Therefore, we consider appropriate to search for energy and entropy exchange mechanisms of the system, which is a region, with the external environment. Entropy for the region as a system can be considered processes/ phenomena, which are not immanently inherent in the specified system, are not its essential, determining features. Manifestations of entropy were mentioned above when characterizing the current state of state regional policy in Ukraine.

Crises of the last decade forced to draw a number of conclusions, given which we consider it appropriate to identify leading trends and prospective directions of regional development to be given close attention: 1) development of import-substituting productions; 2) diversification of the economy; 3 ) reduction in the relative share of employed in material production and increase of employed in non-material one; 4) development of production of highly processed 
products; 5) increase in labour efficiency, value added, growing intellectual component, innovative development; 6) development of industries with the highest multiplicative effect; 7) coordination of actions of the authorities and society; 8) development of collective forms of ownership (cooperatives); 9) clustering; 10) creation of technology and industrial parks; 11) public-private partnership; 12) taking spatial advantages in the placement of productive forces.

Such classical characteristics of the region as "structuredness" and "multidimensionality" define the region as a set of subsystems in the territorial space that necessitates complex development in the territorial aspect. Territorial constraints limit the flow of some developmental factors from the environment in the spatial, economic, and organizational coordinate system. In other words, such regional characteristic as "partial openness" that manifests among other things in certain closeness by territorial and, in particular, economic and organizational features and, as a consequence, in the lack of possibility to attract factors of development from the environment, it requires maximum use of geographical space and land resources through complex spatial development.

As we see, characteristic of the state of regional development, which was given at the beginning of the article, is completely within the scope of the modern definition of entropy. Therefore, it seems relevant to substantiate antientropic paradigm of management of processes of introducing a modern vision of balanced sustainable regional development, which is interpreted through a balance of sustainability and development.

\section{Management imperatives of balanced sustainable regional development}

It should be noted that the modern variety of methodological approaches used in the science of "public administration" gives quite an ambiguous definition of the phenomenon of "entropy". An attempt to combine interpretations of entropy led to the following. Modern understanding of entropy provides for the growth of variability, multivectorness in the system, polyvariety etc. For the XX century, more characteristic is the description of entropy processes through the concepts of "damping", "hindering", "reducing integrity" of the system, "the gap between its connections." Polar, at first sight, approaches describe different stages of "evolutionary function" of entropy: at the expense of multi-vector and polyvariant nature of development, the total energy of the system is divided, broken down, resulting in the inhibition of its "direct" movement. The emergence of additional, alternative capabilities "litters" the system, creating a polyvariety of movement for a single period of time.

In the context of the system of management of regional development, anti-entropy can be interpreted as a purposeful activity for bringing the system to the state that more closely meets the requirements of evolution, for a shorter period of physical time than the complete cycle of "natural" evolution demands. It is obvious that the region, representing a complex multidimensional system, involves principles of effective development inherent in such formations. So, the principle of integrity is reflected in the complex territorial development, the smoothing of territorial disproportions. The principle of optimality finds its expression in optimal development and location of industries in the region. Problems of optimization are considered in papers of many scholars, among which we should mention: W. Lassmann, H. Schilar, K. Schwarz, S. Brentjes (Lassmann, Schilar, Schwarz, Brentjes, 1990).

At the same time, despite characteristics of growth points described in the works of the cited authors, in practice, we face with the latter, which are not onedimensional (industry, region) but multidimensional, when simultaneously determining the leading, priority branch in the association with a certain territory. In this regard, it is more appropriate to talk about the instrument - the territorial-industrial formation (cluster, industrial park, technopark etc.) - as an effective regional locomotive of growth.

Let us consider regional development trends existing at the current development stage of Ukraine by the following directions: 1) sustainable development; 2) innovative-modernization; 3) those having both innovative-modernization and sustainability components. The first block is represented by the following trends: diversification of the economy; development of import-substituting productions; production of highly processed products; reduction in the relative share of employed in material production and increase of employed in non-material one; coordination of actions of the authorities and society; development of collective forms of ownership (cooperatives).

Their realization allows region to pass through crisis phenomena with the slightest downturn in development, because they are oriented either on less dependence on external factors (import substitution, high degree of processing), or on the minimization of adjacent production dependence (diversification), or on the levelling of intra-regional social disturbances (coordination of actions of the authorities and society), or on the stabilization of labour market situation due to increase in employment (creation of cooperatives).

The trend to reduce employed in material production and increase of employed in non-material ones, which comes from innovative-modernization block as a consequence of the increase in labour efficiency and labour saving, relates to a stable block of regional development areas. This is predetermined by a number of factors, in particular, firstly, market supply and demand for non-material works and services are relatively stable since they are less imported from the 
external environment and are poorly exported to the external environment; secondly, demand for services is mostly not elastic in price due to the impossibility of denial of services, even in a crisis (utility services, hairdressing, funeral services), they are refused in the last turn; thirdly, expenditures on consumption of products of the non-material sector, for the most part, occupy an insignificant share in aggregate expenditures. The global crisis of 2008-2010 has clearly demonstrated that monoindustrial regional systems, whose functioning is too dependent on external factors, have faced much more significant socio-economic problems in comparison with regions oriented on domestic demand, where the production of essential commodities is developed, as well as in comparison with regions where production is diversified.

The second block represented by the following prospective areas and tools of regional development - increase in labour efficiency, value added, growing intellectual component, growth in the share of innovative products; clustering; creation of technology and industrial parks; taking spatial advantages; development of public-private partnership - has a pronounced innovative character and thus determines modernization direction of regional development, especially relevant in recent times. The third block, which is a symbiosis of two previous ones, is represented by one perspective area - development of industries with the highest multiplicative effect.

Synthesis of the abovementioned blocks in relation to this area, which envisages realized specifics of antientropic approach, has led to the following conclusions:

1) sustainability is inherent in those industries that operate stably, for example, where products are manufactured, the demand for which is little elastic in price, and which operate stably in the event of a crisis, ensuring the continuity of related industries;

2) modernization-innovative direction finds its expression in the following - in the conditions of crisis recovery, the construction, tourism and other industries are the "locomotives" of regional growth, their development and investment in them give the greatest economic effect. Along with that, in the acute phase of the crisis, the production of products and services in these industries is decreasing, taking also related industries, which does not allow us to consider this promising area as classically sustainable.

In such a way, sustainable block is represented by trends within the alreadyknown principles "optimality", "balance" and "coordination": diversification of the economy; development of import-substituting productions; production of highly processed products; reduction in the relative share of employed in material production and increase of employed in non-material one; coordination of actions of the authorities and society; development of collective forms of ownership (cooperatives).
Modernization-innovative block is represented by perspective areas and tools within the principles of "complexity", "optimality" and "balance": increase in labour efficiency, value added, growing intellectual component, growth in the share of innovative products; clustering; creation of technology and industrial parks; taking spatial advantages; development of public-private partnership.

The symbiosis of sustainability and modernizationinnovative directions is represented by the area of regional development within the principle of optimality: development of industries with the highest multiplicative effect.

We consider understanding and taking into account the whole aggregate of abovementioned perspective areas as imperative in the realization of the management mechanism of balanced sustainable regional development.

\section{Research methodology}

The next stage of realization of the set goal envisages the development of tools capable of providing adequate realization and implementation of the outlined approaches. Modern professional literature substantiates possibilities of the application of synergetic-evolutionary-information approaches to the management. The most famous papers are written by C. Meyer, S. Davis. They describe the theory of adaptive systems, according to which "interaction of selforganization, recombination, selection, and collective evolution lead to the emergence of a new quality of the system" (Meyer, Davis, 2007), which evolved, that is, adapted to the changing environment and meets its requirements.

Modern science and practice of public administration are characterised by attracting managerial principles typical for the commercialsector to public administration tools. "In business, growth serves as a reasonable criterion for the viability of the company" (Meyer, Davis, 2007). The criterion of the viability of a certain organizational structure of public administration authorities at the regional level is the ability to ensure the exercise of powers at the expense of internal for the territory resources, and subsequently - to act as a donor region. For this purpose, it is worth using a new paradigm of management that is "to create a system of views of management focused not on engineering and efficiency but evolution and adaptability" (Meyer, Davis, 2007). Sharing the opinion of researchers, we should specify that the efficiency of management does not cease to be important both the purpose and the characteristic of the required type of management. However, given the constant acceleration of all processes and sides of management (development of subject and object of management, a complex of their environments etc.), it seems appropriate to use the principle of advance. 
Adam Smith also argued that "individual intelligence and individual actions - the only way to create opportunities for adaptation (Smith, 1962). System anti-entropy increases with the increase in the share of "individual" actions, decisions etc. in the organization. Therefore, the circle of people who make managerial decisions in the LPAA, in particular, LGA, needs to be expanded, while increasing individual responsibility and providing decent professional training. Human resource management is an established requirement for the functioning of the organization. A. Toffler proposed an approach that is partly reflected in the current version of the Law of Ukraine "On Civil Service". So, A. Toffler noted: "the work of most people must be diverse, it should not be repeated and should be based on personal responsibility, demand from the person the ability to distinguish, evaluate, and judge" (Toffler, 1984).

If entropy is interpreted as an increase in the spectrum of probable opportunities, the choice of the wrong way option at the point of bifurcation can lead to irreversible deterioration of the situation. It seems necessary to determine an optimal way of regional development among all possible options based on computer modelling. So, sociologists Joshua Epstein and Robert Axtell developed a universal computer model of society "Sugarscape". The program creates models on the basis of elements of adaptive systems: agents (freely operating units), rules, and the environment. The experience described in the professional literature indicates the efficiency of applying this model when making managerial decisions not only within the organization but also within the industrial sector of the state (Epstein Joshua M., Robert Axtell, 1996). Given the fact that the model is in open Internet access, it is expedient to propose local public administration authorities to use it when determining an optimal variant of problemsolving.

Described in foreign professional sources (Höpner, 2005) management methods applied for the commercial sector can be partially adapted to domestic realia of public administration at the regional level. It is, in particular, about the method of "localized innovation" - in the abovementioned source, "all franchises should share new knowledge with other franchises. We create knowledge community." The key is the requirement for obligatory notification to colleagues/organizations - other bodies of local selfgovernment or local executive authorities - about successful innovations in management. It is possible to implement it through the creation of a single information portal, the attraction of leading associations of local self-government bodies. Mandatory requirement for ensuring the effectiveness of this portal is the involvement of experts-analysts, who must provide high-quality scientific support of the disaggregated data provided, by means of generalization; selection of those with a relatively universal character; formulation of proposals for the dissemination and introduction into the legislative practice of the state. Such an approach to the organization of the functioning of portal corresponds to the principle of adaptive management "to create, connect, develop," at which "evolution as such is incorporated not only in production" of this organization "but also in its strategy and management" (Smith, 1962).

On the basis of analysis carried out, in the context of the development of the domestic legislative field, it seems appropriate to amend the Law of Ukraine "On Associations of Local Self-Government Bodies" by provisions on functions in the sphere of determination and dissemination of advanced managerial methods, including at the level of supranational associations of local self-government bodies.

One of the resources for antientropic management on the basis of the adaptive approach requiring the realization of the principle of diversity is multidisciplinary teams. In the context of the problems under study, the realization of this postulate provides for the formation of a body of local self-government officials with diverse professional training, which will allow attracting the full range of modern methodologies of various sciences and wide own managerial experience of officials to solving the problems associated with the introduction of the proposed model of sustainable development. At the same time, all of them should have the necessary training in the field of public management and administration, which will ensure a shared vision of the goal.

Features of adaptive organization (i.e. one that successfully applies antientropic tools) are predetermined by corresponding managerial methods: maximizing the diversity of ideas; ensuring their ability to contact and interact with each other; increase the number of such contacts (Meyer, 2007).

In the context of studying processes of the introduction of a model of sustainable development of the region on the basis of antientropic paradigm, this thesis acquires the following interpretation. Increase in the number of variants for interpreting certain entropic crisis situation, the growth of quantitative indicators of "visions" of the exit from it will lead to the transition to the next qualitative state. The number of contacts among carriers of such approaches will increase them exponentially that will cause inevitability of qualitative leap.

Therefore, in order to more effectively use the potential of recombination, it seems appropriate to conduct competitions of "best practices" not only among local self-government bodies of a certain level but to extend the circle of their participants to all elements of the system of local self-government (including village, settlement, city mayors, chiefs, bodies of self-organization of the population) and local executive authorities, providing at the legislative level, the possibility of transferring certain elements from one branch of public administration to another. 
Interpreted in such a context, "collective evolution" of local self-government bodies and local executive authorities will be realized, probably, by the following ways: through certain competition in the exercise of powers (in the introduction of competition system of their distribution, at which the performer is guaranteed to receive funds for their execution, having previously proved his ability through a special procedure); through cooperation in the exercise of those powers that it is expedient to realize by joint efforts; through the implementation of joint innovations in managerial activity.

On the basis of analysis carried out, in the context of the development of the domestic legislative field of local self-government, it seems appropriate to amend the Law of Ukraine "On Associations of Local SelfGovernment Bodies" by provisions on functions in the sphere of determination and dissemination of advanced managerial methods. In the given context, it seems possible to analyse the organization of activities of supranational associations of local selfgovernment bodies from the viewpoint of management of antientropic processes, which serve as a meaningful pillar of the introduction of the green economy, which is a circle of further promising research.

\section{Conclusions}

It should be emphasized that the listed tools should be used as a single set, providing a synergetic effect in adaptive management of organizational processes associated with the introduction of the modern model of sustainable development.

Summing up, let us note the following. In this study, modern approaches to phenomena of entropy are generalised; antientropic paradigm of management of processes of introducing modern model of balanced development at the regional level are substantiated; on the basis of antientropic paradigm, there is proposed a set of approaches to managing organizational processes in the system of local self-government, which provides permanent dynamic multi-vector interaction of systems (organizations) of different levels and different environments, also it is used for ensuring coherent dissipative activity. Based on the concept of adaptive management, a complex of tools for managing organizational processes in the system of subjects of providing sustainable balanced regional development is elaborated.

In view of this, future research prospects are associated with deepening the study of processes and forms of antientropic management of regional development through the introduction of a model of the green economy.

Tools that are proposed in this research for introducing the model of balanced sustainable regional development on the basis of antientropic paradigm include the following: maintenance of an open state of the system; use of the principle of feed-forward control; realization of the principle of diversity. The presented complex of approaches ensures continuous dynamic multi-vector interaction of systems (organizations) of different levels and different environments.

\section{References:}

Epstein, M. Joshua, Axtell, L. Robert. (1996). Growing Artificial Societies: Social Science from the Bottom Up. London, England: MIT Press.

Höpner, M. (2005). What connects industrial relations and corporate governance? Explaining institutional complementarity. Socio-Economic Review, 3(2), 331-358.

Gumilev, L. N. (2008). Etnohenez y byosfera Zemly. Moscow, Russia: Ajrys-press.

Kantorovych, L. V., Lassmann, W., Schilar, H., Schwarz, K., Brentjes, S. (1990). Ekonomyka i optymyzatsyia. Moscow, Russia: Nauka.

Kylyenene, A., Macherynskene, Y., Navytskas, V., Symanavychene, Zh. (2006, August). Sotsyalno-ekolohycheskoe razvytye rehyonov ES. Sotsiologicheskie issledovaniy, 8, 48-56.

Luniachek, V. E. (2011) Entropiia upravlinska. Entsyklopediia derzhavnoho upravlinnia: u 8 t. (Vol. II). Kyiv, Ukraine: NADU.

Meyer, C. (2007). Zhyvaia orhanyzatsyia: per. s anhl. Moscow, Russia: Dobraia knyha.

Mylner, B. Z. (2000). Teoryia orhanyzatsyy: ucheb. Moscow, Russia: YNFRA-M. Retrieved from: http://www.vuzlib.su/beta3/html/1/4344/4360/

Pro zatverdzhennia Derzhavnoi stratehii rehionalnoho rozvytku na period do 2020 roku: postanova Kabinetu Ministriv Ukrainy vid 06.08.2014 № 385 (2014, August, 06). Retrieved from: https://zakon.rada.gov.ua/laws/ show/385-2014-\%D0\%BF

Smith, A. (1962). Yssledovanye o pryrode y prychynakh bohatstva narodov. Moscow, Russia: Yzdatelstvo sotsyalno-ekonomycheskoj lyteratury.

Toffler, A. (1985). The Adaptive Corporation. London: Pan Books.

Vykliuk, Ya. (2010). Modeliuvannia sotsialno-ekonomichnykh system i rozrakhunok ikh dynamichnykh pokaznykiv na osnovi analohij. Fizyko-matematychne modeliuvannia ta informatsijni tekhnolohii, 11, 24-36. 